\title{
Analysis of Health and Ecological Risks Due Exposure to Particulate Matter (PM 2.5) and the Occurrence of Lung Disease Among School Children in Maros, Indonesia
}

\author{
Anwar Mallongi ( $\sim$ rawnaenvi@yahoo.com ) \\ Hasanuddin University \\ Stang Stang \\ Hasanuddin University \\ Annisa Utami Rauf \\ Hasanuddin University \\ Ratna Dwi \\ Hasanuddin University
}

\section{Research Article}

Keywords: Exposure Risk, Particulate Matter 2.5, Lung Disease, School Children, and Environmental Risk

Posted Date: August 31st, 2021

DOl: https://doi.org/10.21203/rs.3.rs-835674/v1

License: (c) (i) This work is licensed under a Creative Commons Attribution 4.0 International License.

Read Full License 


\section{Abstract}

Background: Assessments and evaluations of particle characteristics (PM) from various sources, become very important to protect humans and the environment. The purpose of this study was to assess the environmental and children health risks due to exposure to breathing air containing PM of 2.5 from the cement industry around the settlement.

Research Methods: The method used in data analysis is linear regression statistical test to determine the relationship between PM2.5 air quality with outdoor activities by children and respiratory disorders experienced. Health risk analysis and environmental risk were calculated using the equations provided by the EPA and WHO. To determine the magnitude of risk received by the environment and children if exposed to PM2.5 within a certain period of time. Direct measurements in the field were carried out in the morning until noon, with 23 sample points measured level of PM 2.5 pollution during June 2021.

Results: The measurement results showed that the highest level of PM 2.5 concentration at the time of measurement was at station 10 in Bungaeja Elementary School, station 17 in Tukamasea Village and station 18 at Miftahul Rahman Mosque, Tukamasea Village with values of $0.490,0.466$ and 0.455 $\mathrm{mg} / \mathrm{m} 3$ respectively. While the lowest is in the location; Salenrang Bontoa Village 1 with a value $(0.060)$, Baruga Village, Near Factory Truck Parking (0.060), and in Salenrang Bontoa Village 2 (0.0905). The results of laboratory analysis for soil samples from 23 points in the research location showed that the highest points were respectively located at the station near the Jabal Rahmah Mosque, Maccini Baji Village, with a concentration of (2876), in the Mattoangin area (2358) and in Dusun Manarang, Tukamasea (2158). On the other hand, the lowest was in Pajjaiyang Hamlet (1083), Bungaeja Village, Tukamasea (1190), and Ammansangeng, Baruga (1263). The calculation of the Potential Hazard Quotient (HQ) for the highest inhalation route is 880.78 , and 852.43 while the lowest is 82.88 and 92.83 . Furthermore, for the HQ value via the dermal route, the highest values were 0.012 and 0.011 while the lowest HQ values were 0.003 and 0.004 all without units. The results of the calculation of ecological risk for ambient air show that the highest and most risky values are 7.54 and 7.15 while the lowest are 0.92 and 1.46 units less. Furthermore, the highest ecological risk values for soil intake were 287 and 235 while the lowest were 119 and 126 without units.

Conclusion: Health risks through the inhalation route all exceed the standard $>1$ and the potential for pulmonary disorders in children can occur, while the risk from the dermal route is still $<1$ which means it is still safe. most of the children that frequently expose to dust of PM 2.5 have experienced to suffer from lung diseases and at risk.

\section{Introduction}

World Health Organization (WHO) states that a polluted environment is estimated to cause 12.6 million deaths globally. Of these deaths, young children contributed $23 \%$ of the total mortality. $26 \%$ of deaths in vulnerable groups, especially the elderly, pregnant women, sufferers of respiratory health problems. 
Children tend to experience breathing problems when continuously inhaling air pollutant particles.[1] Exposure to air pollution at an early age can cause impaired lung development, reduce lung function and increase the risk of chronic lung disease in adulthood. Exposure to PM2.5 which is released from the combustion of the cement industry from its base material, biomass activity and also causes respiratory health in children in particular and also in people who experience other diseases.[2]

Sources of PM2.5 due to human activities are mostly derived from coal burning, industrial processes, forest fires, and exhaust gases from transportation means. Types of industries that have the potential as sources of PM2.5 are iron and steel industry, cement industry, petrochemical industry, paper and pulp, flour mills, textile industry, asbestos factories, insecticide factories, and electronics industry [3]. The most health problems in 2018 were coughs and ARI. Both are health problems related to weather and environmental conditions. The same thing happened at the research location in Maros Regency.

Specifically for the types of diseases suffered by visitors at the Maros Regional General Hospital (RSUD) for the last six years (2013-2018) were cough 12,514, ARI 10,771, primary hypertension 10,577 and Dermatitis and eczema 9,323 sufferer. This shows the high incidence of disease due to air pollution, both the inhalation route and the skin absorption route for particles resulting from industrial activities near settlements $[4,5]$. This research is very important to investigate and analyze the accumulation of Particulate Matter (PM 2.5) pollutant in the air and soil, assess the risk of potential health hazard (HQ) and the ecological risk due to PM2.5 exposure.

\section{Methods}

The method used in data analysis is linear regression statistical test to determine the relationship between PM2.5 ambient air quality with outdoor activities by children and the risk of respiratory disorders experienced. Health risk analysis and ecological risk were calculated using the equations provided by the EPA and WHO. To find out the magnitude of the risk received by the environment and children if exposed to PM2.5 within a certain period of time. 23 ambient air samples and soils were collected near school and community dwelling as shown on the map Fig. 1 below. Then, informed consent is obtained from the parent/legal guardian of children prior to the interview as well as the teacher permission before the school children participated for the data private collection.

Figure 2 visualized the majority of the wind direction in the present study. This wind rose shows the distribution of wind based on maximum wind speed, wind direction at maximum speed and average wind speed $[6,7]$. The dataset was taken from the Meteorological, Climatological, and Geophysical Agency (BMKG) website specifically in June 2021 during the sampling duration. It is necessary to determine the direction of the wind because the association with pollutants distribution and the area that is likely to be affected by particulates carried by the wind $[8,9]$.

The dominant wind direction in June 2021 indicates that the wind are heading towards Southeast and East. This location consisting of residential areas in Tukamasea Village and Bungaeja Village. Resultant vector of this visualization was $109^{\circ}$. 


\section{Results}

\section{Characteristics school children as respondents}

The collection of characteristics school children data were commenced by filling applied questionnaire based on the students answers. Of those 20 children respondents, information associated to gender, age exposure duration in year, hours daily exposure time, body weight, and education were written and recorded voluntarily on the prepared questionnaire sheet, the results is shown on the following Table 1. 
Table 1

Characteristics school children as respondents

\begin{tabular}{|c|c|c|c|c|c|c|c|}
\hline No & Name & Gender & Age & $\begin{array}{l}\text { Exposure } \\
\text { duration } \\
\text { (years) }\end{array}$ & $\begin{array}{l}\text { Exposure } \\
\text { time (hours) }\end{array}$ & $\begin{array}{l}\text { Body } \\
\text { weight } \\
\text { (Kg) }\end{array}$ & Education \\
\hline 1 & Airil Asri & $M$ & 11 & 11 & 8 & 15 & $\begin{array}{l}\text { Primary } \\
\text { School }\end{array}$ \\
\hline 2 & Nur Azizah & $\mathrm{F}$ & 10 & 10 & 7 & 14 & $\begin{array}{l}\text { Primary } \\
\text { School }\end{array}$ \\
\hline 3 & $\begin{array}{l}\text { Ahmad } \\
\text { Fahrisal Ihsan }\end{array}$ & $M$ & 10 & 10 & 7 & 17 & $\begin{array}{l}\text { Primary } \\
\text { School }\end{array}$ \\
\hline 4 & Reval & M & 6 & 6 & 6 & 15.5 & $\begin{array}{l}\text { Primary } \\
\text { School }\end{array}$ \\
\hline 5 & suci & $\mathrm{F}$ & 5 & 5 & 5 & 10 & Preschool \\
\hline 6 & andini & $\mathrm{F}$ & 5 & 5 & 9 & 11 & Preschool \\
\hline 7 & Naila R & $\mathrm{F}$ & 10 & 10 & 7 & 14 & $\begin{array}{l}\text { Primary } \\
\text { School }\end{array}$ \\
\hline 8 & Abi & M & 5 & 5 & 9 & 10 & Preschool \\
\hline 9 & M Rayhan & $M$ & 14 & 14 & 9 & 16 & $\begin{array}{l}\text { Junior } \\
\text { High } \\
\text { School }\end{array}$ \\
\hline 10 & $\begin{array}{l}\text { Syamsurizal } \\
\text { Pratama }\end{array}$ & M & 12 & 12 & 9 & 17 & $\begin{array}{l}\text { Primary } \\
\text { School }\end{array}$ \\
\hline 11 & $\begin{array}{l}\text { Lena Ayu } \\
\text { Indira }\end{array}$ & $\mathrm{F}$ & 12 & 12 & 9 & 15 & $\begin{array}{l}\text { Primary } \\
\text { School }\end{array}$ \\
\hline 12 & Asmiranda & $\mathrm{F}$ & 10 & 10 & 8 & 16 & $\begin{array}{l}\text { Primary } \\
\text { School }\end{array}$ \\
\hline 13 & Airil Anwar & $M$ & 10 & 10 & 10 & 18 & $\begin{array}{l}\text { Primary } \\
\text { School }\end{array}$ \\
\hline 14 & $\begin{array}{l}\text { Muhammad } \\
\text { Fajar }\end{array}$ & $M$ & 11 & 11 & 9 & 18 & $\begin{array}{l}\text { Primary } \\
\text { School }\end{array}$ \\
\hline 15 & Nuralika & $\mathrm{F}$ & 7 & 7 & 8 & 15 & $\begin{array}{l}\text { Primary } \\
\text { School }\end{array}$ \\
\hline 16 & Andi Hanifa & $\mathrm{F}$ & 14 & 14 & 9 & 14.5 & $\begin{array}{l}\text { Junior } \\
\text { High } \\
\text { School }\end{array}$ \\
\hline 17 & Putri Anugrah & $\mathrm{F}$ & 10 & 10 & 10 & 15 & $\begin{array}{l}\text { Primary } \\
\text { School }\end{array}$ \\
\hline
\end{tabular}




\begin{tabular}{|llllllll|}
\hline No & Name & Gender & Age & $\begin{array}{l}\text { Exposure } \\
\text { duration } \\
\text { (years) }\end{array}$ & $\begin{array}{l}\text { Exposure } \\
\text { time (hours) }\end{array}$ & $\begin{array}{l}\text { Body } \\
\text { weight } \\
\text { (Kg) }\end{array}$ & Education \\
\hline 18 & Indra & M & 14 & 14 & 7 & 25 & $\begin{array}{c}\text { Junior } \\
\text { High } \\
\text { School }\end{array}$ \\
\hline 19 & Rasid & M & 13 & 13 & 4 & 28 & $\begin{array}{l}\text { Junior } \\
\text { High } \\
\text { School }\end{array}$ \\
\hline 20 & Kamaruddin & M & 10 & 10 & 8 & 20 & $\begin{array}{c}\text { Primary } \\
\text { School }\end{array}$ \\
\hline
\end{tabular}

Only 20 children were participated on this study due to pandemic covid-19 limitation activities. 11 male and 9 female school children were voluntary interviewed and requested to fill the questionnaire relate to their period of living in the areas and their age as well as the class level. The youngest were 5 year (2) children and the oldest 14 years old (3) students. Then time lowest time period spend on the areas was 5 years while the longest period was 14 years. In addition, daily exposure time range from 4 hours to 10 hours per day.

\section{Concentration of Air Particulate Matter (PM 2.5) Ambient Near Schools and Residential}

PM2.5 measurements were carried out in 23 locations around the school during the month of June 2021. The results of PM2.5 measurements for each location obtained with the average values result as follows in Table 2, where the (National ambient air quality standards according to Regulation Government No. 41 of $1999, \mathrm{PM} 2.5$ is $65 \mathrm{~g} / \mathrm{m} 3$ ) 
Table 2

Average concentration of PM2.5 in Air and Soil at several points near schools, and the time of collection, Maros Regency, South Sulawesi June 2021

\begin{tabular}{|c|c|c|c|c|}
\hline \multirow{2}{*}{$\begin{array}{l}\text { No } \\
\text { Station }\end{array}$} & \multirow[t]{2}{*}{ Decryption of Study Site } & \multirow[t]{2}{*}{$\begin{array}{l}\text { Collection } \\
\text { time }\end{array}$} & \multirow{2}{*}{$\begin{array}{l}\text { Mean of PM } 2.5 \\
\left(\mathrm{mg} / \mathrm{m}^{3}\right) \\
\text { Ambient air }\end{array}$} & \multirow{2}{*}{ 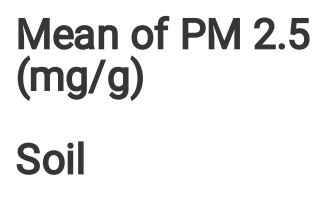 } \\
\hline & & & & \\
\hline 1 & Desa Salenrang, Bontoa 1 & $\begin{array}{l}\text { Morning - } \\
\text { afternoon }\end{array}$ & 0.060 & 1358 \\
\hline 2 & Desa Salenrang, Bontoa 2 & $\begin{array}{l}\text { Morning- } \\
\text { afternoon }\end{array}$ & 0.120 & 1427 \\
\hline 3 & $\begin{array}{l}\text { Desa Baruga, Dekat Parkiran Truk } \\
\text { Pabrik }\end{array}$ & $\begin{array}{l}\text { Morning - } \\
\text { afternoon }\end{array}$ & 0.095 & 1486 \\
\hline 4 & Masjid Tanete, Baruga & $\begin{array}{l}\text { Morning- } \\
\text { afternoon }\end{array}$ & 0.265 & 1463 \\
\hline 5 & Desa Balang, Baruga & $\begin{array}{l}\text { Morning - } \\
\text { afternoon }\end{array}$ & 0.230 & 1836 \\
\hline 6 & Ammasangeng, Baruga & $\begin{array}{l}\text { Morning- } \\
\text { afternoon }\end{array}$ & 0.275 & 1745 \\
\hline 7 & Ammansangeng, Baruga & $\begin{array}{l}\text { Morning - } \\
\text { afternoon }\end{array}$ & 0.315 & 1263 \\
\hline 8 & $\begin{array}{l}\text { Dekat SMPN } 10 \text { Bantimurung, } \\
\text { Bungaeja }\end{array}$ & $\begin{array}{l}\text { Morning- } \\
\text { afternoon }\end{array}$ & 0.330 & 1905 \\
\hline 9 & $\begin{array}{l}\text { Masjid, Depan Rumah Kepala } \\
\text { Desa Tukamasea }\end{array}$ & $\begin{array}{l}\text { Morning - } \\
\text { afternoon }\end{array}$ & 0.290 & 1659 \\
\hline 10 & SD Bungaeja & $\begin{array}{l}\text { Morning- } \\
\text { afternoon }\end{array}$ & 0.490 & 1692 \\
\hline 11 & $\begin{array}{l}\text { Desa Bungaeja (Ujung), } \\
\text { Tukamasea }\end{array}$ & $\begin{array}{l}\text { Morning - } \\
\text { afternoon }\end{array}$ & 0.440 & 1190 \\
\hline 12 & Desa Mattiro Deceng, Lau & $\begin{array}{l}\text { Morning- } \\
\text { afternoon }\end{array}$ & 0.360 & 1492 \\
\hline 13 & Desa Baruga & $\begin{array}{l}\text { Morning - } \\
\text { afternoon }\end{array}$ & 0.365 & 1619 \\
\hline 14 & $\begin{array}{l}\text { Dekat Masjid Siratal Mustaqim, } \\
\text { Baruga }\end{array}$ & $\begin{array}{l}\text { Morning- } \\
\text { afternoon }\end{array}$ & 0.095 & 1830 \\
\hline 15 & Dusun Manarang, Tukamasea & $\begin{array}{l}\text { Morning - } \\
\text { afternoon }\end{array}$ & 0.355 & 2158 \\
\hline 16 & Mattoangin & $\begin{array}{l}\text { Morning- } \\
\text { afternoon }\end{array}$ & 0.435 & 2358 \\
\hline
\end{tabular}




\begin{tabular}{|c|c|c|c|c|}
\hline \multirow{2}{*}{$\begin{array}{l}\text { No } \\
\text { Station }\end{array}$} & Decryption of Study Site & $\begin{array}{l}\text { Collection } \\
\text { time }\end{array}$ & $\begin{array}{l}\text { Mean of PM } 2.5 \\
\left(\mathrm{mg} / \mathrm{m}^{3}\right)\end{array}$ & $\begin{array}{l}\text { Mean of PM } 2.5 \\
(\mathrm{mg} / \mathrm{g})\end{array}$ \\
\hline & & & Ambient air & Soil \\
\hline 17 & Desa Tukamasea & $\begin{array}{l}\text { Morning - } \\
\text { afternoon }\end{array}$ & 0.455 & 1746 \\
\hline 18 & $\begin{array}{l}\text { Masjid Miftahul Rahman, Desa } \\
\text { Tukamasea }\end{array}$ & $\begin{array}{l}\text { Morning- } \\
\text { afternoon }\end{array}$ & 0.465 & 1649 \\
\hline 19 & Dusun Pajjaiyang & $\begin{array}{l}\text { Morning - } \\
\text { afternoon }\end{array}$ & 0.165 & 1083 \\
\hline 20 & Desa Maccini Baji & $\begin{array}{l}\text { Morning- } \\
\text { afternoon }\end{array}$ & 0.180 & 1642 \\
\hline 21 & $\begin{array}{l}\text { Dekat Masjid Jabal Rahmah, } \\
\text { Desa Maccini Baji }\end{array}$ & $\begin{array}{l}\text { Morning - } \\
\text { afternoon }\end{array}$ & 0.325 & 2,876 \\
\hline 22 & Mattiro Deceng, Masjid Balange & $\begin{array}{l}\text { Morning- } \\
\text { afternoon }\end{array}$ & 0.315 & 1753 \\
\hline 23 & SDN 110 Galaggara & $\begin{array}{l}\text { Morning - } \\
\text { afternoon }\end{array}$ & 0.430 & 1937 \\
\hline
\end{tabular}

Direct measurements in the field were carried out in the morning till afternoon, 23 sample points measured for level of PM 2.5 pollution during June 2021. The measurement results showed that the highest concentration of PM 2.5 during the measurement was at station 10 in Bungaeja Elementary School, station 17 in Tukamasea Village and station 18 at the Miftahul Rahman Mosque, Tukamasea Village with value of $0.490,0.466$ and $0.455 \mathrm{mg} / \mathrm{m}^{3}$, respectively. While the lowest were in the location; Salenrang Bontoa Village 1 with a value of (0.060), Baruga Village, Near Factory Truck Parking (0.060), and in Salenrang Bontoa Village 2 (0.0905), respectively.

The results of laboratory analysis for soil samples from 23 points showed that the highest points were located at the station near the Jabal Rahmah Mosque, Maccini Baji Village, with a concentration of (2876), in the Mattoangin area (2358) and in Dusun Manarang, Tukamasea (2158). On the other hand, the lowest was in Pajjaiyang Hamlet (1083), Bungaeja Village, Tukamasea (1190), and Ammansangeng, Baruga (1263), respectively.

\section{Analysis of Children Health Risks and Ecological Risks Due to PM 2.5 Exposure}

Health risk determination is carried out to analyze the level of risk for PM 2.5 pollutant exposure originating from the cement industry. The value obtained comes from the concentration of pollutants in the air and soil media where these values will be compared with the national and international (ecological) quality standard values. In this health risk analysis of PM2.5 pollutants, the risk is 
determined from intake, duration of exposure and pollutant concentration in the body as well as in air and soil media. The higher the risk value obtained, the lower the quality of communities health. The results of the calculation of health and ecological risk analysis are shown in Fig. 3 below.

The results of the calculation of the daily hazard potential hazard quotient $(\mathrm{HQ})$ for the highest via inhalation route were 880.78 and 852.43 while the lowest were 82.88 and 92.83 , respectively. Mean all respondents were at risk. Furthermore, for the $\mathrm{HQ}$ value via the dermal route, the highest values were 0.012 and 0.011 while the lowest $\mathrm{HQ}$ values were 0.003 and 0.004 without units, respectively. The results of the calculation of ecological risk for ambient air show that the highest and most risky values are 7.54 and 7.15 while the lowest are 0.92 and 1.46 without units. Next, the highest ecological risk values for soil are 287 and 235 while the lowest are 119 and 126 unit less, respectively.

\section{Discussion}

The existence of industrial companies operating in Maros Regency deserves attention because a number of factories, especially near settlements, are considered to be still lacking in concern for environmental friendliness and public health concern on heir operation. Especially for pollution such as cement factory dust that obviously pollutes the surrounding environment, although a class action (lawsuit) has not been carried out due to the knowledge limitation among communities to against those factories that are indicated source of pollutant. The results of this research and risk analysis calculations are in fact found the potential hazard and risks both for ecology and human health that presented in the following discussion;

\section{Particulate Matter (PM 2.5) in Ambient Air near Schools and in Settlement}

The emission of ambient air pollution by industry is highly dependent on the type of industry and the process. One of the industries that contribute to air pollution is the cement industry. Atmospheric or ambient emissions associated with cement production include suspended dust, anhydrides, furans, polycyclic aromatic hydrocarbons and metals adhering to volatile particles. Large amounts of dust are emitted at almost every stage of the cement manufacturing process, from extracting the main raw material, limestone, to packing and shipping cement from factories. Cement dust comes in various sizes and shapes, for example particulates with a diameter of less than $2.5 \mathrm{~m}$ and $10 \mathrm{~m}$ (PM2.5 and PM10). [5]

In this study, we measured particulate matter (PM) 2.5 from 23 points to observe the quality ambient air, it showed that the highest concentrations were in three sites, namely $0.490,0.466$ and $0.455 \mathrm{mg} / \mathrm{m}^{3}$. These three areas are located in open areas and close to the main sources of pollution and located not far from schools and dwelling. The amount of concentration exceeds the standard PP No. 41 of 1999, PM2.5 by $65 \mathrm{~g} / \mathrm{m}^{3}$ or $0.065 \mathrm{mg} / \mathrm{m}^{3}$. This fact of course causes by the accumulation of PM2.5 in the air which has the potential to disrupt the health of children who are mostly in school locations and also residential areas. [10] [11] 
Based on WHO Statistics [1], air pollution causes 7 million deaths through indoor and outdoor pollution. The most worrying and striking impact of air pollution is the increasing number of premature deaths in school-age children due to exposure to airborne particles that endanger children's health, such as PM 2.5. The size of the PM 2.5 allows it to penetrate deep into the lungs. Exposure to PM 2.5 in a short time is enough to cause problems with the eyes, nose, throat, lung irritation, coughing, sneezing, runny nose and shortness of breath. PM 2.5 can also impair lung function and worsen asthma and heart disease [11]. A study also published in The Journal of Investigative Medicine revealed that PM 2.5 increases the risk of mouth cancer particularly among children and young age. [12]

Furthermore, according to WHO, PM2.5 resulting from incomplete combustion was found as a major contributing cause lead to worse air quality with generate adverse effects on health as well as bad polluted climate surround. This study in fact shows that exposure to PM10 and PM2.5 will increase the risk of respiratory health disturbance and can induce formation of micronucleus among children who live near the site of industrial activity. A study in addition indicated that exposure to PM2.5 high concentrations increase the risk of both acute and chronic respiratory health problems of elementary school children who live near cement industry activity areas [1,13-15] as particle PM2.5 exposure can lead to micronucleus formation in children.

Although the average concentration of PM2.5 was $\left(29.34 \mathrm{~g} / \mathrm{m}^{3}\right)$, still below the quality standard value according to Government Regulation No. 41 of $1999\left(65 \mathrm{~g} / \mathrm{Nm}^{3}\right)$, it accumulate due to the frequently and long period exposure will potentially generate complicated diseases. As described that, there is an increase in real time intake, 3 years and 12 years, respectively $7.53 \times 10^{-5}, 1.25 \times 10^{-4}, 5.02 \times 10^{-}$ ${ }^{4} \mathrm{mg} / \mathrm{kg} /$ day, respectively. PM2.5 intake was high among students with low body weight compared to students with bigger body weight. [16]

\section{Particulate Matter (PM 2.5) on Surface Soil}

Sources of dust, both PM 2.5 and PM10, which are around the school near the cement industrial area, apart from emissions from industrial activities, also come from the ground surface and asphalt roads where dust particles accumulate from the air. The number of passing vehicles will be lifted and spread so that it will be inhaled by school children who are in the area. This study found that many school children were directly exposed to dust, especially PM. 10 and PM 2.5, especially for schools which are very close to the industry, are often crossed by large trucks carrying goods, and soil dust is also lifted due to vehicular traffic. In addition, the traces of soil on the asphalt immediately spread in all directions, including the school environment. Based on research on health effects on the population living in the cement factory area in Italy.

Researchers grouped the age groups of adults (>34 years) and children (0-14 years). The result is that children become a more risky age group, from the association of factory emissions and hospitalization for cardiovascular and respiratory problems. (6) Another study, namely the analysis of PM2,5 and respiratory disorders in elementary school children showed that the results of the cohort study during One 
month to 142 elementary school children in Palembang City showed that 38.9 percent of children experienced respiratory tract disorders in the form of cough, runny nose with fever or no fever during the observation.

On this study, the highest polluted areas were located at the station near the Jabal Rahmah Mosque Maccini Baji Village, with a concentration of (2876), then Mattoangin area (2358) and in Dusun Manarang, Tukamasea (2158). On the other hand, the lowest were in Pajjaiyang Hamlet (1083), Bungaeja Village, Tukamasea (1190), and Ammansangeng, Baruga (1263), respectively.

Similarly, an increase of $10 \mathrm{~g} / \mathrm{m} 3 \mathrm{PM} 2.5$ will increase deaths from cardiovascular causes by $0.63 \%$ and deaths from respiratory disorders by $0.75 \%$. If exposed to PM10 for a long time the risk of death will increase to $67 \%$. Another study, namely the analysis of PM2.5 and respiratory disorders in elementary school children showed that the results of a one-month cohort study of 142 elementary school children in Palembang City showed that 38.9 percent of children experienced respiratory disorders in the form of coughs, runny noses with fever or not. fever during observation.The distributions of PM2.5 dust particles diameter show a stable $12.27 \%$ weight percentage of total dust weight from 0.4 to 2.1 PM25 has been studied at residence area around the cement factory, Citeureup. In addition, research in Tangará da Serra found a potential average dose of PM2.5 was $1.95 \mu \mathrm{g} / \mathrm{kg}$.day (95\% Cl: 1.62-2.27) during dry scenario and $0.32 \mu \mathrm{g} / \mathrm{kg}$.day (95\% Cl: $0.29-0.34$ ) in the rainy scenario. Children and adolescents showed a toxicological risk to PM2.5 of $2.07 \mu \mathrm{g} / \mathrm{kg}$.day (95\% Cl: 1.85-2 .30) in dry season. [17-18].

The settled particulate dust (PM 2.5) may contain a higher proportion of particulate matter than is present in the air. Several studies show that workers who are exposed to respiratory dust (PM2.5 dust) are more likely to experience impaired lung function with a percentage of $>50 \%[19,20]$. Hastiti's research [21] on employees of PT X, South Kalimantan and Marpaung on permanent traders at the Depok City Integrated Terminal also shows that there is a significant relationship between PM2.5 exposure and impaired lung function. [22, 23]

\section{Ecological and Health Risk Analysis}

Calculation of the value of ecological risk for inhalation by air or dermally through skin contact shows a number that far exceeds the second standard, namely $>1$. This indicates that both the environment and the health of children in the study area are at risk of being contaminated and suffering from illness due to exposure to PM 2.5 within a certain period. The main cause of the high risk of exposure is the proximity of schools and residential areas to the cement industry, as well as the number of passing vehicles which causes a lot of dust particles on the ground surface that accumulate to fly so that they are inhaled or attached to the skin. Related research on exposure to high concentrations of particulate matter exceeding the WHO standard value limits in the school environment for students affected by the location of schools near highways with high traffic density was also found in Hong Kong. [24].

The findings are similar to the results obtained in Maros, Indonesia. A similar study regarding the Risk Analysis of PM 2.5 Exposure in Ambient Daylight on Communities in the Cement Industrial Area in 
Padang City with RQ $>1$ and the results of the calculation of the risk that are accepted for life (lifetime) show that there are three risk areas with an RQ value $>1$, namely Ring 2 (500-1,000 m), Ring $4(1,500$ $2,000 \mathrm{~m})$, and Ring $5(2,000-2,500 \mathrm{~m})$. The safest area that can be inhabited by the community in the cement industrial area is above $2.5 \mathrm{~km}$ from the industrial center with a concentration of $0.028 \mathrm{mg} / \mathrm{m} 3$. PM 2.5 particulates $<2.5 \mu \mathrm{m}$ in diameter are more at risk than PM $10 \mu \mathrm{m}$. These particulates can enter through the lungs to get to the alveoli. The reference concentration value (RfC) for PM2.5 has not been found in the Integrated Risk Information System (IRIS) or Minimum Risk Level (MRL) table, so the reference concentration value for PM2.5 is sought based on the primary standard (primary standard) National Ambient Air Quality Standard (NAAQS) for PM2.5 is $5 \mathrm{~g} / \mathrm{m} 3$ or $0.005 \mathrm{mg} / \mathrm{m} 3$ (annual arithmetic mean). [25-27]

\section{Conclusion}

Most of inhaled particulate matter 2.5 concentrations at the sample points have exceeded the standard PP No. 41 of 1999, PM 2.5 by $65 \mathrm{~g} / \mathrm{m}^{3}$ or $0.065 \mathrm{mg} / \mathrm{m}^{3}$. In addition, PM 2.5 on soil far exceeds the standard determined in all sampling areas. Assessment of Health risks through the inhalation route already $>1$ mean at risk and the potential for pulmonary disorders among children can occur, while risk from the dermal route is still $<1$ which is still safe.

\section{Declarations}

\section{Acknowledgments}

Thanks to all Lecturers of Environmental Health Department, Faculty of Public Health, Hasanuddin University and to thank BTKL for the PM2.5 sampling and analysis accordingly.

\section{Data Availability Statement}

The data used in this study are derived from data on PDBrenum (http:// dunbrack3.fccc.edu/PDBrenum) and can be

\section{Research funding}

All Authors are very grateful to Higher Education Directorate, Republic of Indonesia for the research grand and National Innovation for this research through LPPM of Hasanuddin University.

No: 752/UN4.22/PT.01.03/2021

The funders had no role in study design, data collection and analysis, decision to publish, or preparation of the manuscript.

\section{Author contributions}


Anwar Mallongi: Conceptualization, data curation, Writing-original draft and review - edit

Stang: data calculation and curation, referencing

Ratna Dwi Puji Astuti: Location Observing, data collection and edit draft

Annisa Utami Rauf: Location Observing, data collection and edit draft

\section{Informed consent}

Informed consent was obtained from each participant included in the study.

\section{Conflict of Interest}

The authors have declared that no competing interests within this research and publication exist

\section{Ethical approval}

This study was approved by the Ethical Committee of Medical Faculty of Hasanuddin University, and all methods were carried out in accordance with relevant guidelines and regulations.

\section{References}

1. WHO. (2019). World Health Statistics 2019. Geneva.

2. Anwar Mallongi, P Parkpian, P Pataranawat, S Chinwetkitvanich, 2015, Mercury Distribution and its Potential Environmental and Health Risks in Aquatic Habitat at Artisanal Buladu Gold Mine in Gorontalo Province, Indonesia, Pakistan Journal of Nutrition

3. Wardhana, W.A. 2004. Dampak Pencemaran Lingkungan (Edisi Revisi). Yogyakarta: Penerbit Andi

4. Dinas Kesehatan Kabupaten Maros 2019

5. US.EPA. National Ambient Air Quality Standards (NAAQS) [Internet]. 2012. Available from: https://www.epa.gov/criteria-air-pollutants/naaqs-table.

6. Reiminger, N. et al. (2020) 'Methodologies to assess mean annual air pollution concentration combining numerical results and wind roses', Sustainable Cities and Society, 59, p. 102221. doi: https://doi.org/10.1016/j.scs.2020.102221.

7. Tsai, C. W. et al. (2020) 'Development of a noise-assisted multivariate empirical mode decomposition framework for characterizing PM 2.5 air pollution in Taiwan and its relation to hydro-meteorological factors', Environment International, 139, p. 105669. doi: https://doi.org/10.1016/j.envint.2020.105669.

8. Fenech, S. et al. (2019) 'Meteorological drivers and mortality associated with 03 and PM2.5 air pollution episodes in the UK in 2006', Atmospheric Environment, 213, pp. 699-710. doi: https://doi.org/10.1016/j.atmosenv.2019.06.030. 
9. Rauf, A. U. et al. (2021) 'Community Health Risk Assessment of Total Suspended Particulates near a Cement Plant in Maros Regency , Indonesia', Journal of Health and Pollution, 11(30). doi: 10.5696/2156-9614-11.30.210616.

10. Ekowati, R. 2012. Analisis Risiko Paparan Debu (Linen Dust) terhadap Gangguan Fungsi Paru. Tesis. Surabaya: Universitas Airlangga.

11. Tekno and Sains, 2019., Memahami PM 2,5 dan PM 10 yang Jadi Indikator Tingkat Polusi Udara., 26 Juni 2019

12. Kumparan SAINS, 2018, Polusi Udara Tingkatkan Risiko Kanker Mulut, The Journal of Investigative Medicine .,18 Oktober 2018.

13. Santiasih, I. 2012. Paparan Partikulat (PM10 dan PM2,5) Terhadap Tenaga Kerja di Dalam Ruangan. Paper and Presentation of Environment Engineering.

14. Amqam, H., Thalib, D., Anwar, D., Sirajuddin, S., Mallongi, A. Human health risk assessment of heavy metals via consumption of fish from Kao Bay. Reviews on Environmental Health. 2020; https://doi.org/10.1515/reveh-2020-0023

15. Anwar Mallongi, Poranee Pataranawat, Preeda Parkpian, 2014, Mercury Distribution and its Potential Environmental and Health Risks in Aquatic Habitat at Artisanal Buladu Gold Mine in Gorontalo Province, Indonesia, Pakistan Journal of Nutrition

16. Ony Rosalia, Bambang Wispriyono, Haryoto Kusnoputranto., Characteristic of Health Risks on Students Due to Dust Inhalation Exposure of Particulate Matter <2.5 (PM2,5)., JURNAL MKMI, Vol. 14 No. 1, Maret 2018

17. Lu, F., Xu, D., Cheng, Y., Dong, S., Guo, C., Jiang, X., \& Zheng, X. (2015). Systematic review and metaanalysis of the adverse health effects of ambient PM2,5 and PM10 pollution in the Chinese population. Environmental Research, 136, 196-204. doi: 10.1016/j.envres.2014.06.029.

18. de Oliveira, B.F.A., Ignotti, E., Artaxo, P. et al. Risk assessment of $\mathrm{PM}_{2.5}$ to child residents in Brazilian Amazon region with biofuel production. Environ Health 11, 64 (2012). https://doi.org/10.1186/1476069X-11-64

19. Marpaung, Y. M. (2012). Pengaruh Pajanan Debu Respirable PM2,5Terhadap Kejadian Gangguan Fungsi Paru Pedagang Tetap di Terminal Terpadu Kota Depok Tahun 2012.

20. Aulia, Z. (2014). Analisis Kadar PM2,5 dan Fungsi Paru Pekerja di Industri Cecek Desa Katerungan Kecamatan Krian Kabupaten Sidoarjo. Skripsi. Surabaya: Universitas Airlangga.

21. Hastiti, L. R. (2013). Pajanan PM2,5 dan Gangguan Fungsi Paru Serta KadarProfil Lipid Darah (HDL, LDL, Kolesterol Total, Trigliserida) pada Karyawan PT X, Kalimantan Selatan Tahun 2012. Jurnal Kesehatan Lingkungan. Depok: FKM UI

22. EPA (Environmental Protection Agency). 2013. Particulate Matter (PM) Research. Diakses dari www.epa.gov/ pm (Sitasi tanggal 31 Januari 2014).

23. Xia, Y., et al., Prevalence of Pneumoconiosis in Hubei, China from 2008 to 2013. International Journal of Environmental Research and Public Health, 2014. 11(9): p. 8612 
24. S.C Lee MC. Indoor and Outdoor Air Quality Investigation at Schools in Hong Kong. Chemosphere. 2000

25. Schwartz, J., \& Neas, L. M. (2000). Fine particles are more strongly associated than coarse particles with acute respiratory health effects in schoolchildren. Epidemiology, 11(1), 6- 10.

26. Ferina Rahim, Yeremiah R. Camin, 2018., Indoor Air Quality (So2, No2, Pm10 And Pm2,5) In Houses And Respiratory Disorders Involved, Available online at AL-KAUNIYAH: Journal of Biology Website: http://journal.uinjkt.ac.id/index.php/kauniyah.

27. Reni Suhelmi, Hasnawati Amqam, Ridwan M. Thaha, Anwar Mallongi, Anwar Daud and Hasanuddin Ishaq., The relationship of mercury exposure with neurological problems in artisanal gold in Makassar city., Reviews on Environmental Health. 2020; https://doi.org/10.1515/reveh-2020-0034

\section{Figures}

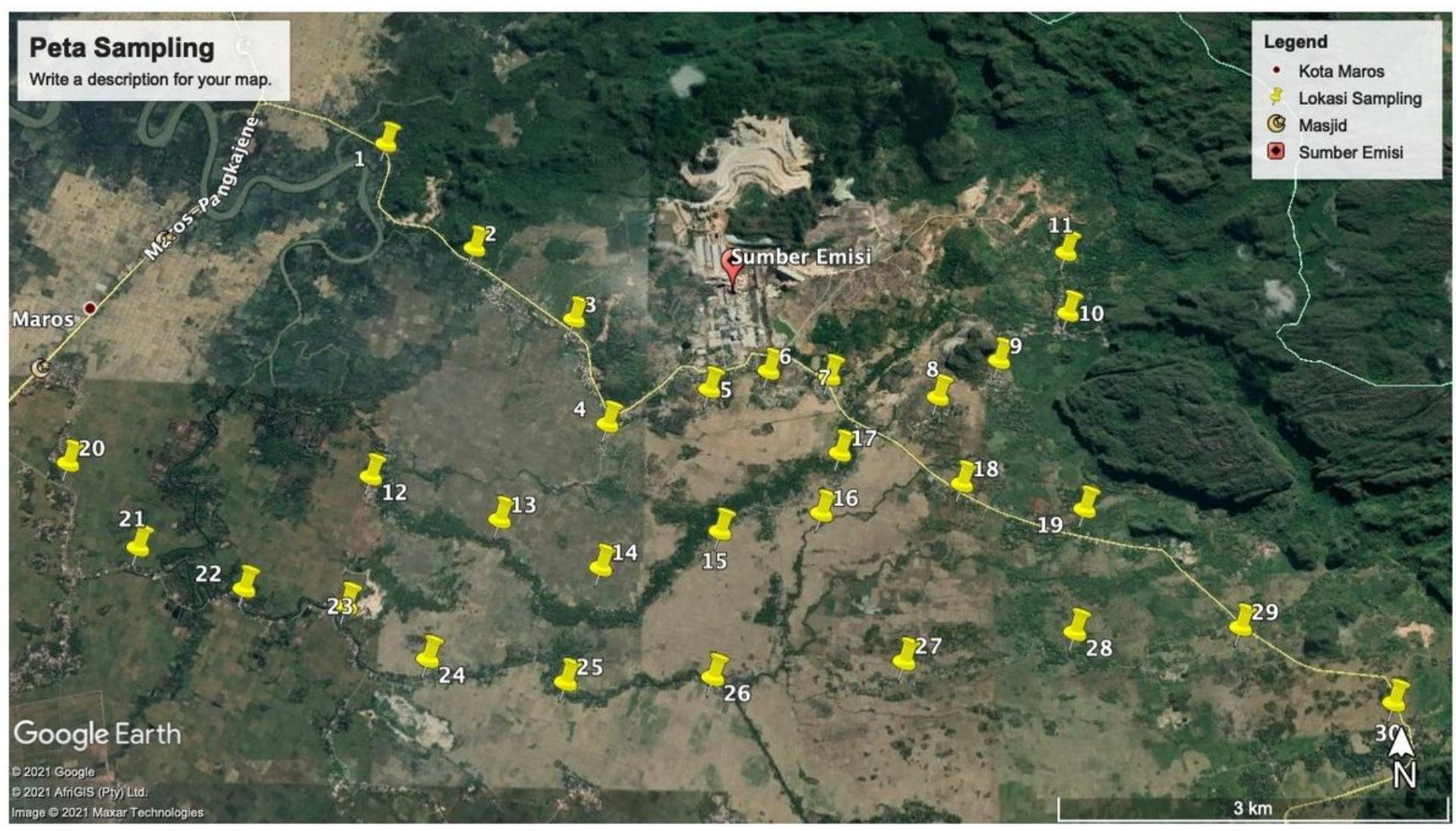

\section{Figure 1}

Map of Study site Source: Google Earth Pro Software 

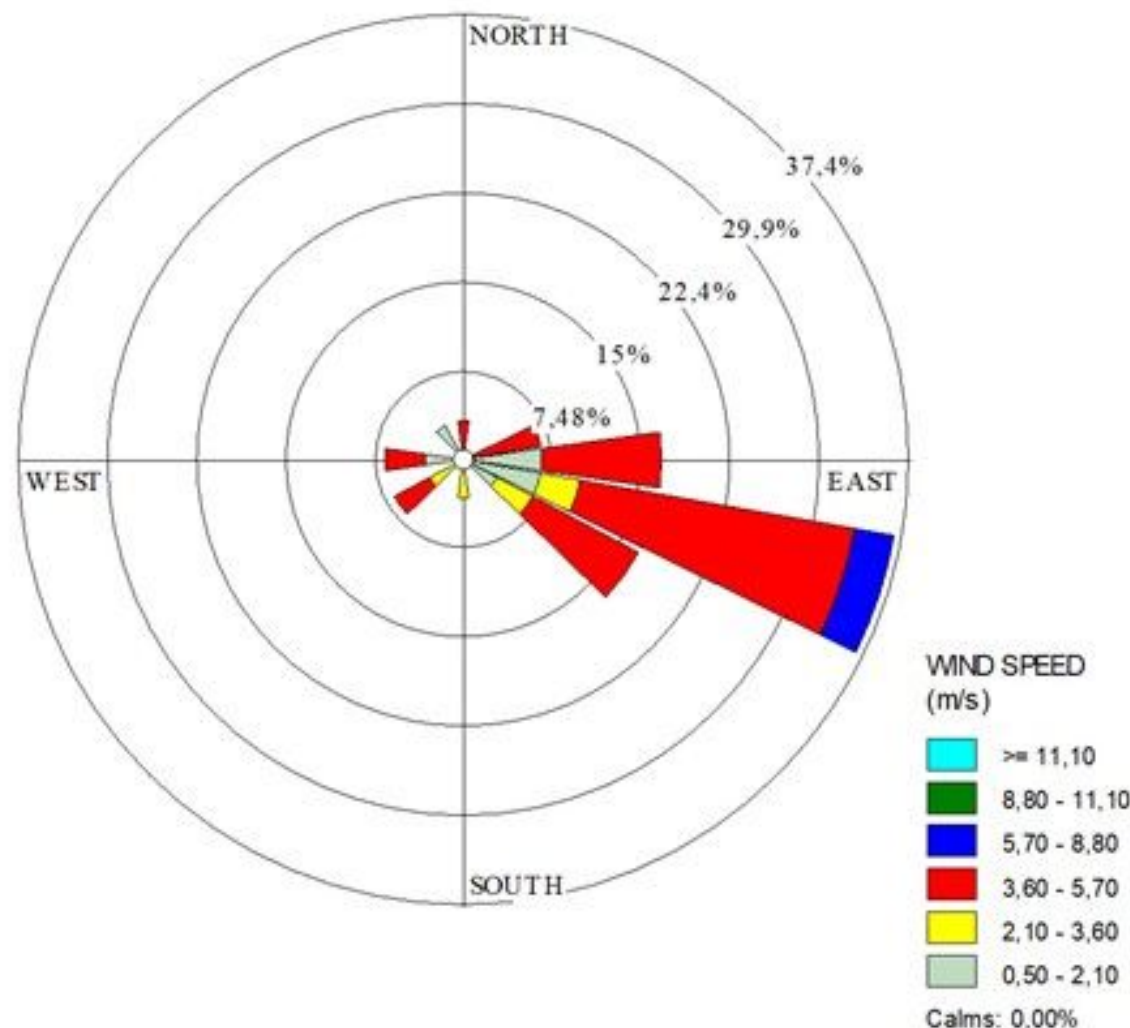

Figure 2

Wind direction during June 2021 Source: Lakes Environmental WRPLOT View V.8.0.2

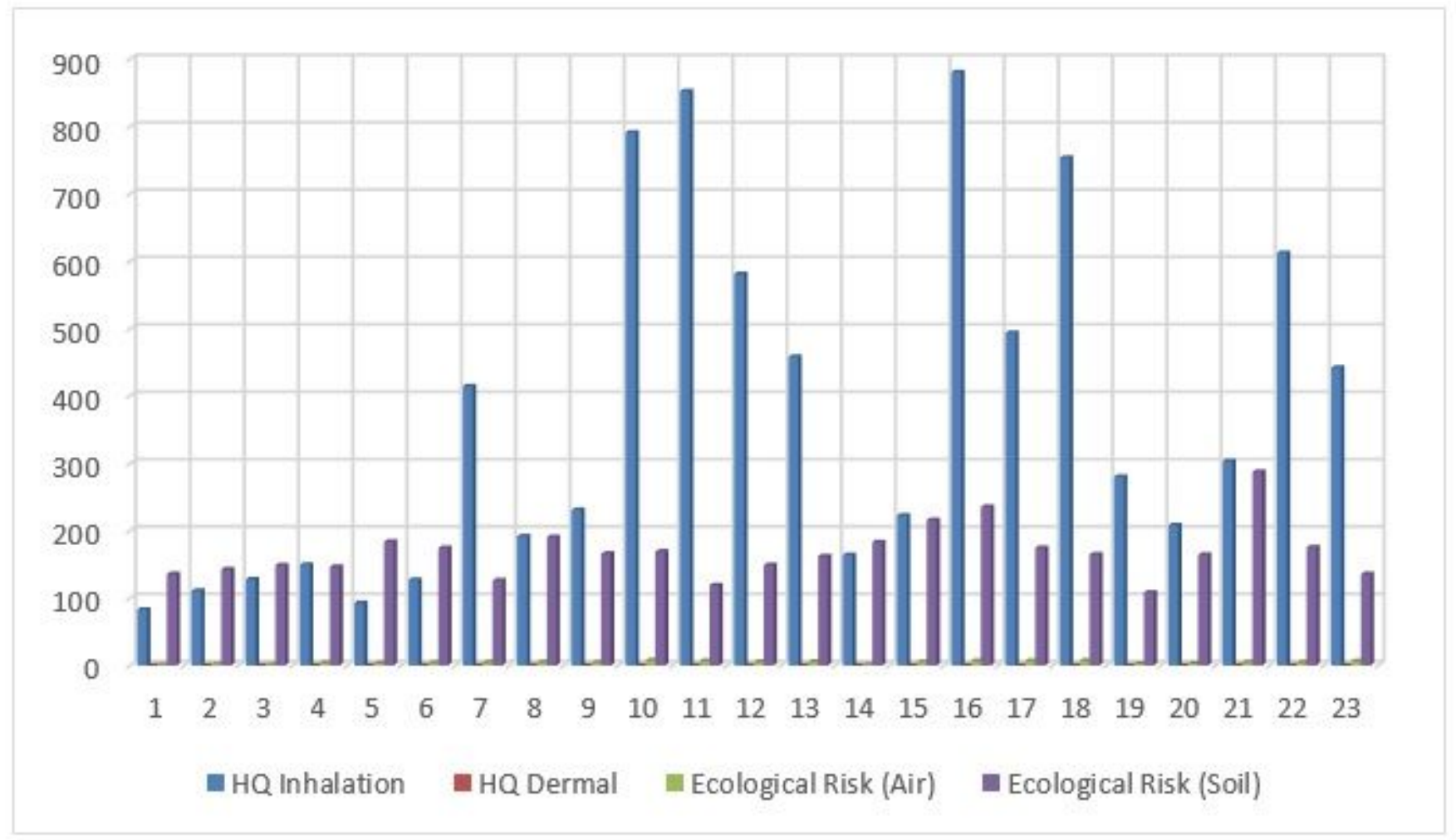

Figure 3 
Analysis of Potential Hazards Hazard Quotient (HQ), and Ecological Risks from the air and ground surface Near School, Maros Regency, June 2021. 